Research Article

\title{
Fuzzy Logic Application for Drought Risk Determination in Kulon Progo Regency, Daerah Istimewa Yogyakarta Province, Indonesia
}

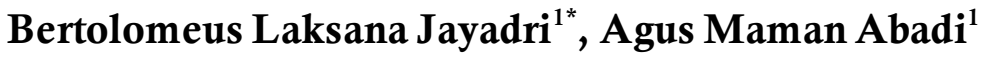 \\ ${ }^{1}$ Department of Mathematics, Universitas Negeri Yogyakarta, Indonesia \\ *Corresponding author: bertolomeuslaksana.2017@student.uny.ac.id
}

Received: 5 February 2021; Accepted: 24 May 2021; Published: 18 June 2021

\begin{abstract}
This study aims to determine the drought risk of Kulon Progo Regency using fuzzy logic and study the characteristics. The input variables used in this study are the drought level, exposed population, and vulnerable population. The Mamdani method used in the fuzzy inference to obtain the output variable, that is, the Drought Risk Index (DRI). Then, the DRI are mapped to generate the drought risk map. The result shows that the fuzzy logic can be used to determine the drought risk. The drought risk level of the subdistricts in Kulon Progo Regency was fluctuated from 2010 to 2019. The drought risk level in 2010-2015 and 2019 were dominated by the low category. Meanwhile, the drought risk level in 20162018 was dominated by the very low category. Furthermore, the result also shows that the subdistricts located in the southern region of Kulon Progo Regency had a higher risk than those in the middle and northern regions during the last 10 years.
\end{abstract}

Keywords: Fuzzy logic, Drought, Kulon Progo

\section{Introduction}

Fuzzy theory was first introduced by Lotfi A. Zadeh in 1965. Fuzzy theory can be classified into five major branches, namely fuzzy mathematics; fuzzy logic and artificial intelligence; fuzzy systems; uncertainty and information; and fuzzy decision making. These five branches are not independent and there are strong interconnections among them. For example, fuzzy control uses concepts from fuzzy mathematics and fuzzy logic. Logic is the study of methods and principles of reasoning, where reasoning means obtaining new propositions from existing propositions. In classical logic, the propositions are required to be either true or false, that is, the truth value of a proposition is either 0 or 1 . Fuzzy logic generalizes classical logic by allowing the truth of values of a proposition to be any number in the interval $[0,1]$. This generalization allows us to perform approximate reasoning, that is, deducing imprecise conclusions from a collection of imprecise premises [1].

Fuzzy logic is extremely useful for many people involved in research and development including engineers, mathematicians, computer software developers, natural scientists, medical researcher, social scientists, public policy analyst, business analyst, and jurists. Fuzzy logic can be used to handle information arising from perceptual computing and cognition, that is, uncertain, imprecise, indistinct, partially true, or indefinitely. New computational methods based on fuzzy logic can be used in the development of intelligent system for decision making, identification, pattern recognition, optimization, and control [2]. In 2012, Özger, Mishra, and Singh [3] used the wavelet and fuzzy logic combination model for forecasting the drought in Texas. Lewis, Fitts, Kelly, and Dale [4] in 2014 used a spatial suitability model based on fuzzy logic to map the drought of an area in the United States for the placement of Switchgrass (Panicum virgatum). Then, in 2020, Malik, Kumar, Salih, Kim, Kim, Yaseen, and Singh [5] used an advanced fuzzy logic model to predict the drought index in Kumaon, India.

This study aims to determine the drought risk of Kulon Progo Regency using fuzzy logic and study the characteristics. Drought is an unpredictable natural hazard caused by the deficiency of precipitation [6]. This hazard can have a very broad impact, such as on the economic, social, health, education, and other sectors. Based on the characteristics and impacts, drought can be classified into four types, that is, meteorological drought, agricultural drought, hydrological drought, and socio-economic drought [7]. A study about the drought is significant because it can be used to plan drought disaster management in the future. Therefore, the impacts of the drought can be minimized [8]. 
This study uses three input variables, that is, the drought level, exposed population, and vulnerable population. It is based on the study by Sun, Zhang, Zhang, Hu, Yan, and Wang [9] in 2014 about the drought and waterlogging risk zoning using fuzzy comprehensive evaluation in Anhui Province, China. The indicators commonly used to determine the drought level are the $z$ index, Palmer Drought Severity Index (PDSI), Standardized Precipitation Index (SPI), $k$ index, Bhalme-Mooley Drought Severity Index (BMDI), and others. This study uses the SPI to determine the drought level, because it has a strong correlation with drought reports from the government [10]. Moreover, the SPI uses a simple input, that is, the precipitation, but it can represent drought conditions in a certain timescale.

The SPI was developed by McKee, Doesken, and Kleist [11] in 1993. The SPI is obtained from historical precipitation data, where the accumulation over the period is compared to the same period throughout the historical data at any location. This index represents the probability of the location would have received at least an observed amount of precipitation over the time period. The SPI is calculated based on the representation of the historical precipitation data with gamma distribution. Positive SPI values represent wet conditions and negative SPI values represent dry conditions. The SPI can be computed for multiple timescales, where the time period is in $i$ months, for $i=3,6,12,24$, or 48 . This study uses the 12-month SPI to determine the drought level. The 12-months SPI calculated by comparison of precipitation for 12 consecutive months with historical precipitation data in the same 12 consecutive months in all previous years of the available data. The 12-months SPI represents long-term precipitation patterns and related to the streamflow, reservoir levels, and groundwater levels. Therefore, this SPI can be used for hydrological drought analysis and applications [12].

The fuzzy logic used to determine the drought risk because the input variables contain uncertainty. In the fuzzy inference, the Mamdani method used to obtain the output variable, that is, the Drought Risk Index (DRI). This index shows the risk of drought in a certain area and time. This index has an interval of $[0,1]$. If the DRI approaches to 1 , the drought risk is higher, and vice versa. The final step of this study is mapping the DRI to generate the drought risk map. Based on this map, information about changes in the drought risk over a certain period can be obtained. This study has never been done before. The authors hope that this result can be considered by the local government and related agencies in the efforts to mitigate the drought in Kulon Progo Regency.

\section{Methods \\ Data Collection}

This study used a time period of 10 years (2010-2019). The selection of a long time period was expected to provide an overview of the drought risk pattern in Kulon Progo Regency. The SPI calculation was carried out using data of monthly precipitation with the data length of 27 years (1993-2019). The monthly precipitation data were obtained from BPS-Statistics of Kulon Progo Regency [13]. The ideal length of the data for calculating the SPI is between 20-30 years [12]. After calculating the SPI, the SPI were averaged by year to obtain the annual average. These values in 2010-2019 were used for the drought level input.

The data used to determine the exposed and vulnerable populations were total area data, population data based on sex and population data based on ages group in 2010-2019. These data were available annually and can be obtained from the publication of BPS [13, 14]. This study also used data of people with disabilities in 2010-2019 for the vulnerable populations. These data were available annually and can be obtained from the Social Service for Women's Empowerment and Child Protection of Kulon Progo Regency [15].

\section{Drought Level Determination}

The drought level was determined based on the 12 -month SPI. The SPI was calculated using SPI Generator 1.7.5. This program was developed by National Drought Mitigation Center (NDMC) and can be obtained from http://drought.unl.edu/droughtmonitoring/SPI/SPIProgram/aspx. In this study, there were several weather stations in certain years that were unable to provide the data of precipitation. Therefore, the missing data were analyzed using the average method because the calculation using the program requires complete precipitation data. The average method is a practical method that can be used to determine the missing data of precipitation [16]. This method can be calculated as follows

$$
p_{j}=\frac{\sum_{i=1}^{n} p_{i j}}{n}
$$

where $p_{j}$ is the missing data at $j$ th months, $n$ is the number of weather stations, and $p_{i j}$ is the precipitation at $i$ th station at $j$ th months, for $i=1,2, \ldots, n$ and $j=1,2, \ldots, m$. After calculating the SPI using the complete data, the SPI were averaged by year to obtain the annual average. These values in 2010-2019 were used for the drought level input. 


\section{Exposed Population Determination}

The exposed population determined based on the population density. The population density is the comparison between the number of population and total area in a certain area and time. This ratio can be calculated as follows

$$
P D=\frac{N P}{A}
$$

where $P D$ is the population density, $N P$ is the number of population, and $A$ is the total area in square kilometers. These values are used for the exposed population input.

\section{Vulnerable Population Determination}

The vulnerable population determined based on the three indicators, that is, the sex ratio, dependency ratio, and ratio of people with disabilities. It is based on the regulation about the disaster risk assessment in Indonesia issued by the National Disaster Management Authority [17] in 2012. Then, each indicator is weighted by $10 \%$ and accumulated. These values are used for the vulnerable population input.

- The sex ratio is the comparison between the male and female population in a certain area and time.

This ratio can be calculated as follows

$$
S R=\frac{P_{m}}{P_{f}}
$$

where $S R$ is the sex ratio, $P_{m}$ is the male population, and $P_{f}$ is the female population.

- The dependency ratio is the comparison between the number of population ages 0-14 and 65 above, that is, not in the labor force, and the number of population ages 15-64, that is, labor force, in a certain area and time. This ratio can be calculated as follows

$$
D R=\frac{P_{0-14}+P_{65+}}{P_{15-64}}
$$

where $D R$ is the dependency ratio, $P_{0-14}$ is the number of population ages $0-14, P_{15-64}$ is the number of population ages 15-64, and $P_{65+}$ is the number of population ages 65 above.

- The ratio of people with disabilities is the comparison between the number of people with disabilities and the number of population in a certain area and time. This ratio can be calculated as follows

$$
R P D=\frac{P_{d}}{N P}
$$

where $R P D$ is the ratio of people with disabilities, $P_{d}$ is the number of people with disabilities, and $N P$ is the number of population.

\section{Fuzzy Membership Function Determination}

Table 1 shows the steps of determining the fuzzy membership function for each variable, that is, preceded by defining the universal set and the domain. Then, the graph of membership function for the input and output variables are mapped using MATLAB R2015a. These graphs are shown in Figures 1 to 4 .

\section{Fuzzy Rules Determination}

The number of fuzzy sets of the drought level, exposed population, and vulnerable population consecutively are 5, 3, and 3 . Therefore, there are 45 complete fuzzy rules used in this study. These rules are obtained from the collaboration with the expert, that is, the Regional Disaster Management Agency of Kulon Progo Regency. The examples of these rules are shown in Table 2.

\section{Fuzzy Inference and Defuzzification}

The Mamdani method is used in the fuzzy inference, while the defuzzification uses the centroid method. The output of this step is the DRI. The Mamdani fuzzy inference and defuzzification are performed using MATLAB R2015a.

\section{Drought Risk Mapping}

The DRI of the subdistricts in Kulon Progo Regency are mapped to generate the drought risk map in 2010-2019. This step is performed using ArcGIS 10.8. The steps for the drought risk determination using fuzzy logic are shown in Figure 5. 
Table 1. The fuzzy sets of the input and output variables

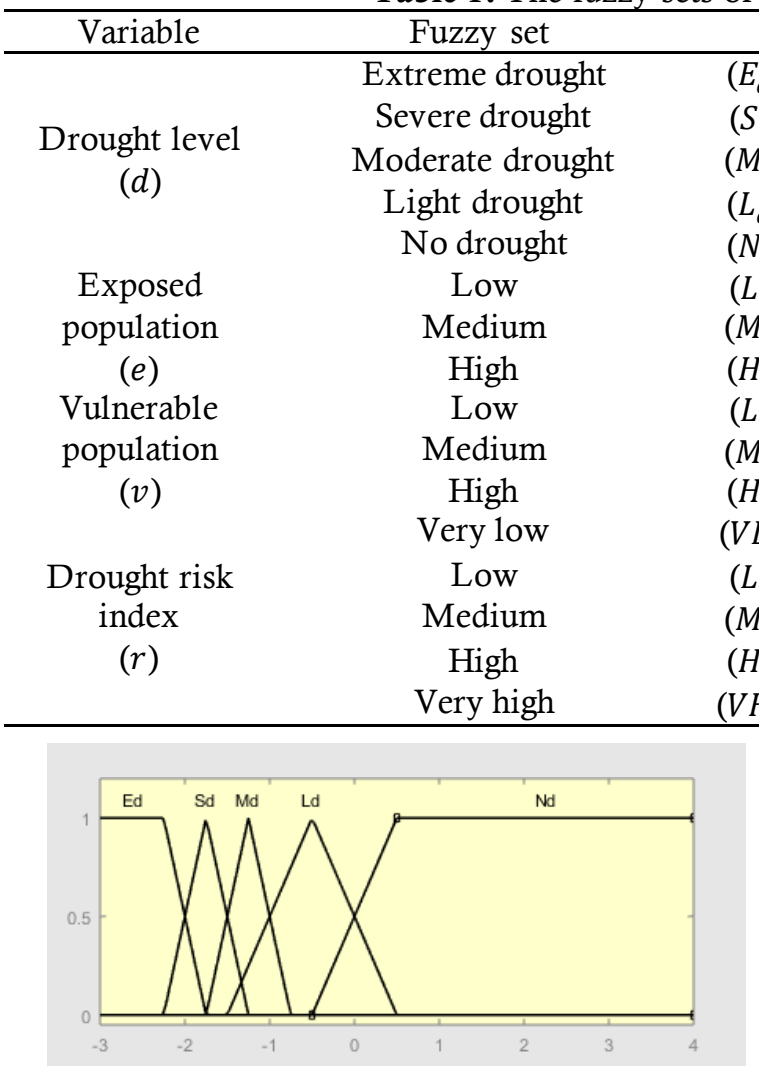

\begin{tabular}{|c|c|}
\hline Universal set & Domain \\
\hline \multirow{5}{*}[-3,4]{} & {$\left[\begin{array}{lllll}-3 & -3 & -2.25 & -1.75]\end{array}\right.$} \\
\hline & {$[-2.25-1.75-1.25]$} \\
\hline & {$\left[\begin{array}{lll}-1.75 & -1.25 & -0.75]\end{array}\right]$} \\
\hline & {$\left[\begin{array}{llll}-1 & .5 & -0.5 & 0.5\end{array}\right]$} \\
\hline & {$\left[\begin{array}{llll}-0.5 & 0.5 & 4 & 4\end{array}\right]$} \\
\hline \multirow{4}{*}[200,1600]{} & {$\left[\begin{array}{lllll}200 & 200 & 250 & 750\end{array}\right]$} \\
\hline & {$\left[\begin{array}{llll}250 & 750 & 1250\end{array}\right]$} \\
\hline & {$\left[\begin{array}{lllll}750 & 1250 & 1600 & 1600\end{array}\right]$} \\
\hline & 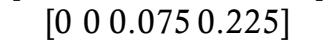 \\
\hline \multirow[t]{4}{*}[0,0.5]{} & {$\left[\begin{array}{llll}0.075 & 0.225 & 0.375\end{array}\right]$} \\
\hline & {$\left[\begin{array}{lllll}0.225 & 0.375 & 0.5 & 0.5\end{array}\right]$} \\
\hline & {$\left[\begin{array}{lll}0 & 0 & 0.25\end{array}\right]$} \\
\hline & {$\left[\begin{array}{llll}0 & 0.25 & 0.5\end{array}\right]$} \\
\hline \multirow[t]{3}{*}[0,1]{} & {$\left[\begin{array}{llll}0.25 & 0.5 & 0.75\end{array}\right]$} \\
\hline & {$\left[\begin{array}{lll}0.5 & 0.75 & 1\end{array}\right]$} \\
\hline & {$\left[\begin{array}{llll}0.75 & 1 & 1\end{array}\right]$} \\
\hline
\end{tabular}

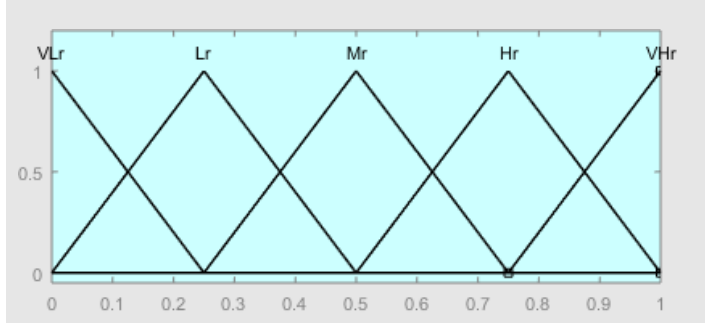

Figure 1. The graph of membership function for the drought level $(d)$ [11]

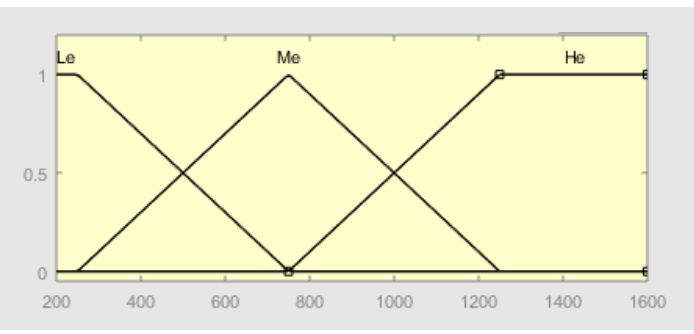

Figure 3. The graph of membership function for the exposed population $(e)$ [17]
Figure 2. The graph of membership function for the DRI $(r)[7,9]$

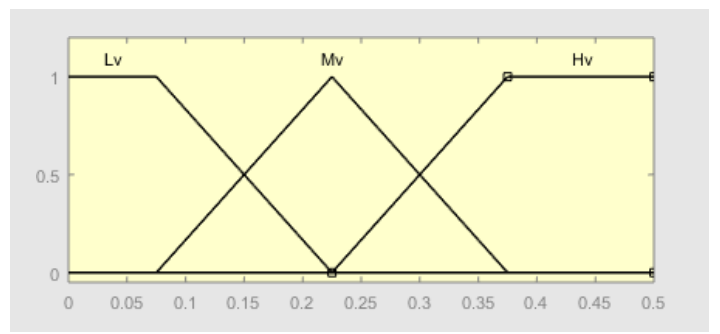

Figure 4. The graph of membership function for the vulnerable population $(v)$ [17]

Table 2. The fuzzy rules Fuzzy rules

1 If the drought level is $N_{d}$ and the exposed population is $L_{e}$ and the vulnerable population is $L_{v}$, then the DRI is $V L_{r}$

2 If the drought level is $N_{d}$ and the exposed population is $L_{e}$ and the vulnerable population is $M_{v}$, then the DRI is $V L_{r}$

45 If the drought level is $E_{d}$ and the exposed population is $H_{e}$ and the vulnerable population is $H_{v}$, then the DRI is $V H_{r}$ 


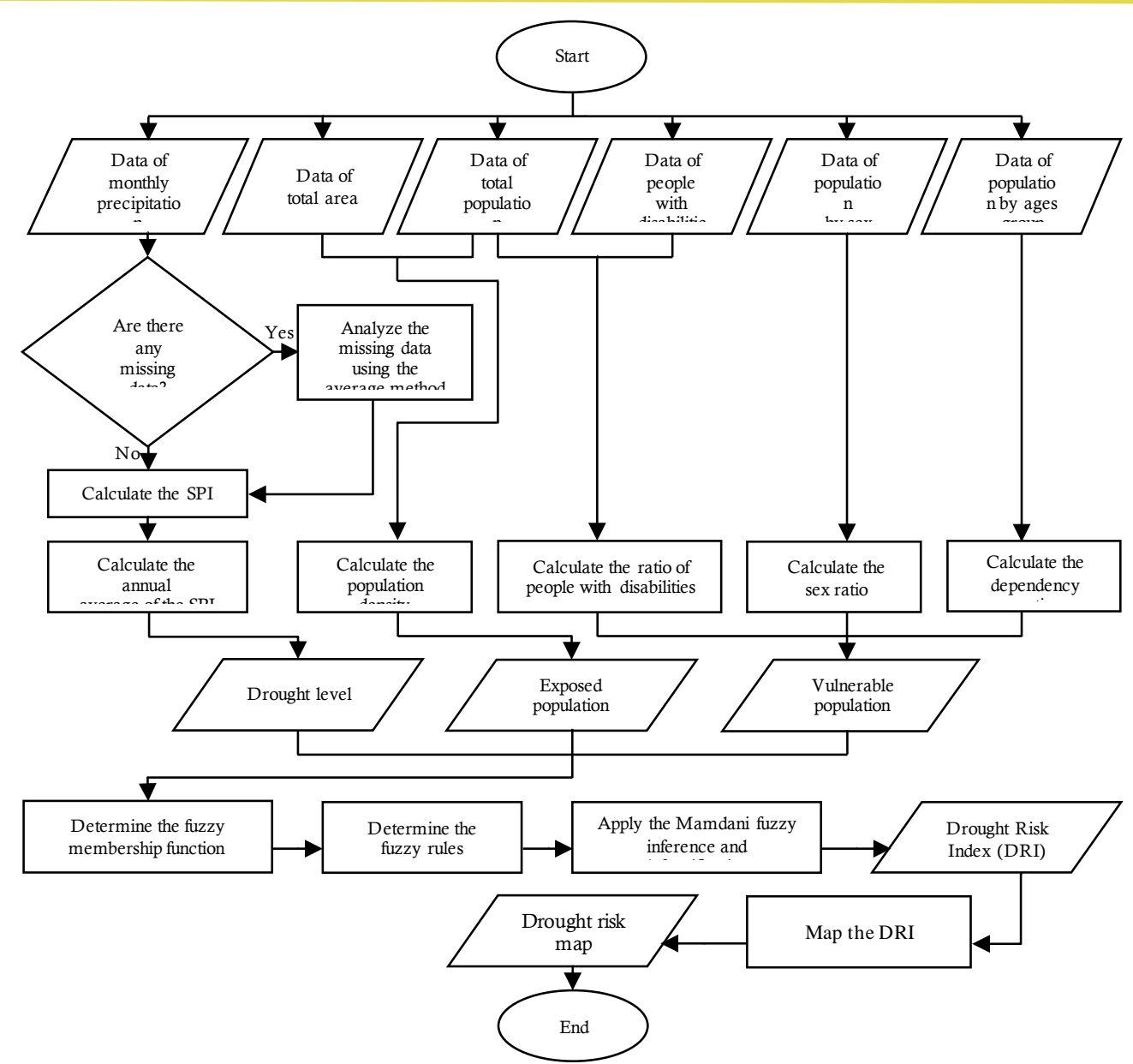

Figure 5. Flowchart of the drought risk determination using fuzzy logic.

\section{Result and Discussion}

One of the factors that influence the amount of precipitation is the elevation of an area. The higher an area is, the more precipitation it will receive, and vice versa. The greatest amount of precipitation will occur in area with the elevation between 600-900 meters above sea level [18]. The highest area of Kulon Progo Regency is the northern region. The northern region is the Menoreh plateau with the elevation between 500-1,000 meters above sea level. This area consists of Girimulyo, Nanggulan, Kalibawang, and Samigaluh Subdistricts [19].

The middle and southern regions of Kulon Progo Regency are hills and lowlands area. The middle region has an elevation between 100-500 meters above sea level. This area consists of Sentolo, Pengasih, and Kokap Subdistricts. While, the southern region has an elevation up to 100 meters above sea level. This area consists of Temon, Wates, Panjatan, Galur, and Lendah Subdistricts [19].

The amount of precipitation received by the northern region will be more than other regions because it is affected by the elevation. However, the southern region will have a higher risk of drought. Therefore, the drought risk analysis was carried out to study the characteristics of the drought in each region. The results of the drought risk in Kulon Progo Regency are shown in Tables 3 to 12.

Table 3 shows that the average drought level in all subdistricts in Kulon Progo Regency is -0.441. This value indicates that the drought level in 2010 was dominated by the light drought category. It is also shown in Table 3 that light drought occurred in most of the subdistricts, except for Kokap, Nanggulan, and Kalibawang Subdistricts. In addition, Table 3 also shows that the exposed and vulnerable populations were dominated by the medium category with the average values of 723.283 and 0.151 . Thus, in 2010 , the drought risk level in all subdistricts in the northern, middle, and southern regions were in a low category.

Table 4 shows that the average drought level in all subdistricts has increased from the previous year to 0.385 . This value indicates that the drought level in 2011 was dominated by the no drought category. It is also shown in Table 4 that drought did not occur in most of the subdistricts, except in Girimulyo Subdistrict. In addition, Table 4 also shows that the exposed and vulnerable populations were dominated 
by the medium category with the average values of 730.735 and 0.151 . Thus, in 2011 , the drought risk level in 7 out of 12 subdistricts were in a low category. These subdistricts were mostly scattered in the southern region. Meanwhile, the middle and northern regions were dominated by subdistricts with very low risk.

Table 3. The input and output data of the subdistricts in Kulon Progo Regency in 2010

\begin{tabular}{lccccc}
\hline Subdistrict & $\begin{array}{c}\text { Drought } \\
\text { Level }\end{array}$ & $\begin{array}{c}\text { Exposed } \\
\text { Population }\end{array}$ & $\begin{array}{c}\text { Vulnerable } \\
\text { Population }\end{array}$ & DRI & $\begin{array}{c}\text { Drought } \\
\text { Risk Level }\end{array}$ \\
\hline Temon & -0.660 & 676.116 & 0.154 & 0.221 & Low \\
Wates & -0.920 & 1378.844 & 0.141 & 0.349 & Low \\
Panjatan & -0.608 & 751.110 & 0.155 & 0.222 & Low \\
Galur & -0.622 & 887.147 & 0.152 & 0.219 & Low \\
Lendah & -0.395 & 1026.890 & 0.152 & 0.223 & Low \\
Sentolo & -0.524 & 848.110 & 0.152 & 0.219 & Low \\
Pengasih & -0.447 & 734.804 & 0.148 & 0.216 & Low \\
Kokap & -1.128 & 422.669 & 0.152 & 0.332 & Low \\
Girimulyo & -0.266 & 399.709 & 0.149 & 0.200 & Low \\
Nanggulan & 0.202 & 689.624 & 0.149 & 0.200 & Low \\
Kalibawang & 0.280 & 507.270 & 0.154 & 0.185 & Low \\
Samigaluh & -0.208 & 357.108 & 0.156 & 0.181 & Low \\
\hline \multicolumn{1}{c}{ Average } & -0.441 & 723.283 & 0.151 & 0.231 & \\
\hline
\end{tabular}

Table 4. The input and output data of the subdistricts in Kulon Progo Regency in 2011

\begin{tabular}{lccccc}
\hline Subdistrict & $\begin{array}{c}\text { Drought } \\
\text { Level }\end{array}$ & $\begin{array}{c}\text { Exposed } \\
\text { Population }\end{array}$ & $\begin{array}{c}\text { Vulnerable } \\
\text { Population }\end{array}$ & DRI & $\begin{array}{c}\text { Drought } \\
\text { Risk Level }\end{array}$ \\
\hline Temon & 0.391 & 684.435 & 0.154 & 0.151 & Low \\
Wates & 0.233 & 1395.844 & 0.148 & 0.194 & Low \\
Panjatan & 0.107 & 759.565 & 0.155 & 0.208 & Low \\
Galur & 0.238 & 895.442 & 0.151 & 0.194 & Low \\
Lendah & 0.075 & 1038.129 & 0.152 & 0.213 & Low \\
Sentolo & 0.523 & 858.234 & 0.152 & 0.094 & Very Low \\
Pengasih & 0.304 & 743.870 & 0.148 & 0.179 & Low \\
Kokap & 0.720 & 424.472 & 0.152 & 0.094 & Very Low \\
Girimulyo & -0.147 & 401.658 & 0.149 & 0.201 & Low \\
Nanggulan & 0.499 & 697.223 & 0.149 & 0.095 & Very Low \\
Kalibawang & 1.072 & 509.894 & 0.153 & 0.094 & Very Low \\
Samigaluh & 0.599 & 360.052 & 0.156 & 0.093 & Very Low \\
\hline \multicolumn{1}{c}{ Average } & 0.385 & 730.735 & 0.151 & 0.151 & \\
\hline
\end{tabular}

Table 5 shows that the average drought level in all subdistricts has decreased from the previous year to $-0,714$. This value indicates that the drought level in 2012 was dominated by the light drought category. It is also shown in Table 5 that light drought occurred in most of the subdistricts, except in Lendah and Samigaluh Subdistricts. In addition, Table 5 also shows that the exposed and vulnerable populations were dominated by the medium category with averages values of 738.136 and 0.151 . Thus, in 2012 the drought risk level in all subdistricts in the northern, middle, and southern regions were in a low category, like the conditions in 2010.

Table 6 shows that the average drought level in all subdistricts has increased from the previous year to -0.101 . This value indicates that the drought level in 2013 was dominated by the light drought category. It is also shown in Table 6 that light drought occurred in 5 of 12 subdistricts, namely Temon, Panjatan, Kokap, Nanggulan, and Samigaluh Subdistricts. In addition, Table 6 also shows that the exposed and vulnerable populations were dominated by the medium category with the average values of 745.482 and 
0.149. Thus, in 2013, the drought risk level in 8 out of 12 subdistricts were in a low category. These subdistricts were mostly scattered in the southern and northern regions.

Table 5. The input and output data of the subdistricts in Kulon Progo Regency in 2012

\begin{tabular}{lccccc}
\hline Subdistrict & $\begin{array}{c}\text { Drought } \\
\text { Level }\end{array}$ & $\begin{array}{c}\text { Exposed } \\
\text { Population }\end{array}$ & $\begin{array}{c}\text { Vulnerable } \\
\text { Population }\end{array}$ & DRI & $\begin{array}{c}\text { Drought } \\
\text { Risk Level }\end{array}$ \\
\hline Temon & -0.768 & 692.755 & 0.153 & 0.236 & Low \\
Wates & -0.476 & 1412.813 & 0.147 & 0.250 & Low \\
Panjatan & -0.572 & 767.952 & 0.154 & 0.221 & Low \\
Galur & -0.990 & 903.616 & 0.151 & 0.340 & Low \\
Lendah & -1.064 & 1049.284 & 0.152 & 0.359 & Low \\
Sentolo & -0.715 & 868.357 & 0.152 & 0.219 & Low \\
Pengasih & -0.528 & 752.887 & 0.147 & 0.215 & Low \\
Kokap & -0.093 & 426.206 & 0.152 & 0.206 & Low \\
Girimulyo & -0.909 & 403.552 & 0.148 & 0.318 & Low \\
Nanggulan & -0.868 & 704.797 & 0.148 & 0.296 & Low \\
Kalibawang & -0.444 & 512.462 & 0.153 & 0.220 & Low \\
Samigaluh & -1.144 & 362.953 & 0.155 & 0.308 & Low \\
\hline \multicolumn{1}{c}{ Average } & -0.714 & 738.136 & 0.151 & 0.266 & \\
\hline
\end{tabular}

Table 6. The input and output data of the subdistricts in Kulon Progo Regency in 2013

\begin{tabular}{lccccc}
\hline Subdistrict & $\begin{array}{c}\text { Drought } \\
\text { Level }\end{array}$ & $\begin{array}{c}\text { Exposed } \\
\text { Population }\end{array}$ & $\begin{array}{c}\text { Vulnerable } \\
\text { Population }\end{array}$ & DRI & $\begin{array}{c}\text { Drought } \\
\text { Risk Level }\end{array}$ \\
\hline Temon & -0.968 & 701.102 & 0.153 & 0.335 & Low \\
Wates & 0.073 & 1429.719 & 0.141 & 0.208 & Low \\
Panjatan & -0.254 & 776.318 & 0.154 & 0.221 & Low \\
Galur & -1.194 & 911.699 & 0.151 & 0.362 & Low \\
Lendah & 3.294 & 1060.326 & 0.152 & 0.094 & Very Low \\
Sentolo & -1.593 & 878.424 & 0.152 & 0.535 & Medium \\
Pengasih & 0.478 & 761.953 & 0.147 & 0.108 & Very Low \\
Kokap & -0.803 & 427.859 & 0.142 & 0.252 & Low \\
Girimulyo & 0.013 & 405.392 & 0.148 & 0.201 & Low \\
Nanggulan & -0.107 & 712.295 & 0.148 & 0.216 & Low \\
Kalibawang & 0.827 & 514.917 & 0.153 & 0.094 & Very Low \\
Samigaluh & -0.982 & 365.781 & 0.143 & 0.295 & Low \\
\hline \multicolumn{1}{c}{ Average } & -0.101 & 745.482 & 0.149 & 0.243 & \\
\hline
\end{tabular}

Table 7 shows that the average drought level in all subdistricts has decreased from the previous year to -0.275 . This value indicates that the drought level in 2014 was dominated by the light drought category. It is also shown in Table 7 that light drought occurred in 4 of 12 subdistricts, namely Sentolo, Pengasih, Kokap, and Girimulyo Subdistricts. In addition, Table 7 also shows that the exposed and vulnerable populations were dominated by the medium category with the average values of 752.757 and 0.150 . Thus, in 2014, the drought risk level in 8 out of 12 subdistricts were in a low category. These subdistricts were mostly scattered in the middle and northern regions.

Table 8 shows that the average drought level in all subdistricts has increased from the previous year to -0.139 . This value indicates that the drought level in 2015 was dominated by the light drought category. It is also shown in Table 8 that light drought occurred in 5 of 12 subdistricts, namely Wates, Kokap, Girimulyo, Kalibawang, and Samigaluh Subdistricts. In addition, Table 8 also shows that the exposed and vulnerable populations were dominated by the medium category with the average values of 759.951 and 0.151 . Thus, in 2015 , the drought risk level in 8 out of 12 subdistricts were in a low category. These subdistricts were mostly scattered in the southern and northern regions. 
Table 7. The input and output data of the subdistricts in Kulon Progo Regency in 2014

\begin{tabular}{lccccc}
\hline Subdistrict & $\begin{array}{c}\text { Drought } \\
\text { Level }\end{array}$ & $\begin{array}{c}\text { Exposed } \\
\text { Population }\end{array}$ & $\begin{array}{c}\text { Vulnerable } \\
\text { Population }\end{array}$ & DRI & $\begin{array}{c}\text { Drought } \\
\text { Risk Level }\end{array}$ \\
\hline Temon & -1.379 & 709.366 & 0.153 & 0.455 & Medium \\
Wates & -1.088 & 1446.531 & 0.147 & 0.387 & Medium \\
Panjatan & 0.225 & 784.638 & 0.154 & 0.194 & Low \\
Galur & 0.254 & 919.629 & 0.143 & 0.187 & Low \\
Lendah & 0.975 & 1071.340 & 0.152 & 0.094 & Very Low \\
Sentolo & -0.044 & 888.414 & 0.152 & 0.219 & Low \\
Pengasih & -0.316 & 770.937 & 0.147 & 0.215 & Low \\
Kokap & -0.372 & 429.458 & 0.151 & 0.208 & Low \\
Girimulyo & -0.578 & 407.158 & 0.148 & 0.202 & Low \\
Nanggulan & 0.360 & 719.717 & 0.148 & 0.163 & Low \\
Kalibawang & 0.019 & 517.315 & 0.153 & 0.215 & Low \\
Samigaluh & -1.361 & 368.581 & 0.154 & 0.419 & Medium \\
\hline \multicolumn{1}{c}{ Average } & -0.275 & 752.757 & 0.150 & 0.247 & \\
\hline
\end{tabular}

Table 8. The input and output data of the subdistricts in Kulon Progo Regency in 2015

\begin{tabular}{lccccc}
\hline Subdistrict & $\begin{array}{c}\text { Drought } \\
\text { Level }\end{array}$ & $\begin{array}{c}\text { Exposed } \\
\text { Population }\end{array}$ & $\begin{array}{c}\text { Vulnerable } \\
\text { Population }\end{array}$ & DRI & $\begin{array}{c}\text { Drought } \\
\text { Risk Level }\end{array}$ \\
\hline Temon & 0.791 & 717.576 & 0.153 & 0.094 & Very Low \\
Wates & -0.792 & 1463.250 & 0.147 & 0.286 & Low \\
Panjatan & 0.667 & 792.846 & 0.153 & 0.094 & Very Low \\
Galur & 0.181 & 927.499 & 0.151 & 0.203 & Low \\
Lendah & 0.086 & 1082.186 & 0.151 & 0.212 & Low \\
Sentolo & 1.314 & 898.367 & 0.151 & 0.094 & Very Low \\
Pengasih & -1.987 & 779.825 & 0.147 & 0.651 & High \\
Kokap & -0.803 & 430.962 & 0.151 & 0.258 & Low \\
Girimulyo & -0.663 & 408.871 & 0.147 & 0.201 & Low \\
Nanggulan & 0.393 & 727.114 & 0.148 & 0.151 & Low \\
Kalibawang & -0.843 & 519.581 & 0.152 & 0.285 & Low \\
Samigaluh & -0.018 & 371.338 & 0.154 & 0.189 & Low \\
\hline \multicolumn{1}{c}{ Average } & -0.139 & 759.951 & 0.151 & 0.226 & \\
\hline
\end{tabular}

Table 9 shows that the average drought level in all subdistricts has increased from the previous year to 0.410 . This value indicates that the drought level in 2016 was dominated by the no drought category. It is also shown in Table 8 that drought did not occur in most of the subdistricts, except in Wates, Galur, Lendah, and Girimulyo Subdistricts. In addition, Table 9 also shows that the exposed and vulnerable populations were dominated by the medium category with the average values of 767.036 and 0.151 . Thus, in 2016, the drought risk level in 7 out of 12 subdistricts were in a very low category. These subdistricts were mostly scattered in the middle and northern regions. Meanwhile, the southern region was dominated by subdistricts with low risk.

Table 10 shows that the average drought level in all subdistricts has increased from the previous year to 1.423 . This value indicates that the drought level in 2017 was dominated by the no drought category. It is also shown in Table 10 that drought did not occur in all subdistricts of Kulon Progo Regency. The change in the drought level value was influenced by a significant increase of precipitation as a result of the Cempaka Tropical Cyclone. This cyclone formed in the Indian Ocean and caused a heavy rainfall, strong winds and thunderstorms in several areas of Indonesia. In addition, Table 10 also shows that the exposed and vulnerable populations were dominated by the medium category with the average values of 773.983 and 0.151 . Thus, in 2017 , the drought risk level for all subdistricts in the northern, middle, and southern regions were in a very low category. 
Table 9. The input and output data of the subdistricts in Kulon Progo Regency in 2016

\begin{tabular}{lccccc}
\hline Subdistrict & $\begin{array}{c}\text { Drought } \\
\text { Level }\end{array}$ & $\begin{array}{c}\text { Exposed } \\
\text { Population }\end{array}$ & $\begin{array}{c}\text { Vulnerable } \\
\text { Population }\end{array}$ & DRI & $\begin{array}{c}\text { Drought } \\
\text { Risk Level }\end{array}$ \\
\hline Temon & 0.333 & 725.702 & 0.153 & 0.171 & Low \\
Wates & -0.271 & 1479.813 & 0.147 & 0.241 & Low \\
Panjatan & 0.658 & 800.964 & 0.154 & 0.093 & Very Low \\
Galur & -0.861 & 935.187 & 0.151 & 0.294 & Low \\
Lendah & -0.172 & 1092.919 & 0.152 & 0.233 & Low \\
Sentolo & 0.517 & 908.205 & 0.151 & 0.094 & Very Low \\
Pengasih & 0.481 & 788.696 & 0.147 & 0.106 & Very Low \\
Kokap & 0.908 & 432.358 & 0.151 & 0.094 & Very Low \\
Girimulyo & -0.124 & 410.419 & 0.147 & 0.202 & Low \\
Nanggulan & 1.163 & 734.385 & 0.148 & 0.094 & Very Low \\
Kalibawang & 1.173 & 521.771 & 0.152 & 0.094 & Very Low \\
Samigaluh & 1.116 & 374.008 & 0.154 & 0.093 & Very Low \\
\hline \multicolumn{1}{c}{ Average } & 0.410 & 767.036 & 0.151 & 0.151 & \\
\hline
\end{tabular}

Table 10. The input and output data of the subdistricts in Kulon Progo Regency in 2017

\begin{tabular}{lccccc}
\hline Subdistrict & $\begin{array}{c}\text { Drought } \\
\text { Level }\end{array}$ & $\begin{array}{c}\text { Exposed } \\
\text { Population }\end{array}$ & $\begin{array}{c}\text { Vulnerable } \\
\text { Population }\end{array}$ & DRI & $\begin{array}{c}\text { Drought } \\
\text { Risk Level }\end{array}$ \\
\hline Temon & 1.467 & 733.719 & 0.153 & 0.094 & Very Low \\
Wates & 0.913 & 1496.156 & 0.147 & 0.094 & Very Low \\
Panjatan & 1.443 & 808.948 & 0.154 & 0.093 & Very Low \\
Galur & 1.292 & 942.692 & 0.151 & 0.094 & Very Low \\
Lendah & 0.725 & 1103.428 & 0.151 & 0.094 & Very Low \\
Sentolo & 1.588 & 917.892 & 0.151 & 0.094 & Very Low \\
Pengasih & 1.692 & 797.421 & 0.147 & 0.094 & Very Low \\
Kokap & 0.878 & 433.645 & 0.151 & 0.094 & Very Low \\
Girimulyo & 0.455 & 411.931 & 0.147 & 0.122 & Very Low \\
Nanggulan & 1.717 & 741.530 & 0.149 & 0.094 & Very Low \\
Kalibawang & 2.268 & 523.810 & 0.152 & 0.094 & Very Low \\
Samigaluh & 2.636 & 376.620 & 0.154 & 0.093 & Very Low \\
\hline \multicolumn{1}{c}{ Average } & 1.423 & 773.983 & 0.151 & 0.096 & \\
\hline
\end{tabular}

Table 11 shows that the average drought level in all subdistricts has decreased from the previous year to 0.552 . This value indicates that the drought level in 2018 was dominated by the no drought category. It is also shown in Table 10 that drought did not occur in most of the subdistricts, except in Kokap Subdistrict. In addition, Table 10 also shows that the exposed and vulnerable populations were dominated by the medium category with the average values of 780.771 and 0.151 . Thus, in 2018 , the drought risk level in 7 out of 12 subdistricts were in a very low category, almost like the conditions in 2016. These subdistricts were mostly scattered in the middle and northern regions. Meanwhile, the southern region was dominated by subdistricts with low risk.

Table 12 shows that the average drought level in all subdistricts has decreased from the previous year to -0.285 . This value indicates that the drought level in 2019 was dominated by the light drought category. It is also shown in Table 12 that light drought occurred in 6 of 12 subdistricts, namely Temon, Wates, Galur, Lendah, Girimulyo, and Kalibawang Subdistricts. In addition, Table 12 also shows that the exposed and vulnerable populations were dominated by the medium category with the average values of 787.393 and 0.151 . Thus, in 2019, the drought risk level in most of the subdistricts were in a low category, except in Samigaluh Subdistrict. 
Table 11. The input and output data of the subdistricts in Kulon Progo Regency in 2018

\begin{tabular}{lccccc}
\hline Subdistrict & $\begin{array}{c}\text { Drought } \\
\text { Level }\end{array}$ & $\begin{array}{c}\text { Exposed } \\
\text { Population }\end{array}$ & $\begin{array}{c}\text { Vulnerable } \\
\text { Population }\end{array}$ & DRI & $\begin{array}{c}\text { Drought } \\
\text { Risk Level }\end{array}$ \\
\hline Temon & 0.542 & 741.625 & 0.153 & 0.094 & Very Low \\
Wates & 0.100 & 1512.250 & 0.147 & 0.210 & Low \\
Panjatan & 0.462 & 816.775 & 0.154 & 0.117 & Very Low \\
Galur & 0.274 & 949.954 & 0.151 & 0.187 & Low \\
Lendah & 0.019 & 1113.740 & 0.152 & 0.216 & Low \\
Sentolo & 0.755 & 927.407 & 0.151 & 0.094 & Very Low \\
Pengasih & 0.997 & 806.033 & 0.147 & 0.094 & Very Low \\
Kokap & -0.688 & 434.810 & 0.151 & 0.209 & Low \\
Girimulyo & 0.013 & 413.315 & 0.147 & 0.203 & Low \\
Nanggulan & 1.405 & 748.498 & 0.148 & 0.094 & Very Low \\
Kalibawang & 1.667 & 525.718 & 0.152 & 0.094 & Very Low \\
Samigaluh & 1.083 & 379.131 & 0.154 & 0.093 & Very Low \\
\hline \multicolumn{1}{c}{ Average } & 0.552 & 780.771 & 0.151 & 0.142 & \\
\hline
\end{tabular}

Table 12. The input and output data of the subdistricts in Kulon Progo Regency in 2019

\begin{tabular}{lccccc}
\hline Subdistrict & $\begin{array}{c}\text { Drought } \\
\text { Level }\end{array}$ & $\begin{array}{c}\text { Exposed } \\
\text { Population }\end{array}$ & $\begin{array}{c}\text { Vulnerable } \\
\text { Population }\end{array}$ & DRI & $\begin{array}{c}\text { Drought } \\
\text { Risk Level }\end{array}$ \\
\hline Temon & -0.103 & 749.394 & 0.153 & 0.220 & Low \\
Wates & -0.493 & 1528.063 & 0.147 & 0.250 & Low \\
Panjatan & 0.086 & 824.423 & 0.154 & 0.210 & Low \\
Galur & -0.697 & 957.004 & 0.151 & 0.219 & Low \\
Lendah & -0.486 & 1123.827 & 0.152 & 0.239 & Low \\
Sentolo & 0.187 & 936.752 & 0.152 & 0.201 & Low \\
Pengasih & -1.087 & 814.466 & 0.147 & 0.347 & Low \\
Kokap & -1.118 & 435.867 & 0.151 & 0.336 & Low \\
Girimulyo & -0.360 & 414.572 & 0.148 & 0.203 & Low \\
Nanggulan & 0.169 & 755.365 & 0.148 & 0.204 & Low \\
Kalibawang & -0.091 & 527.455 & 0.152 & 0.219 & Low \\
Samigaluh & 0.566 & 381.527 & 0.154 & 0.093 & Very Low \\
\hline \multicolumn{1}{c}{ Average } & -0.285 & 787.393 & 0.151 & 0.228 & \\
\hline
\end{tabular}




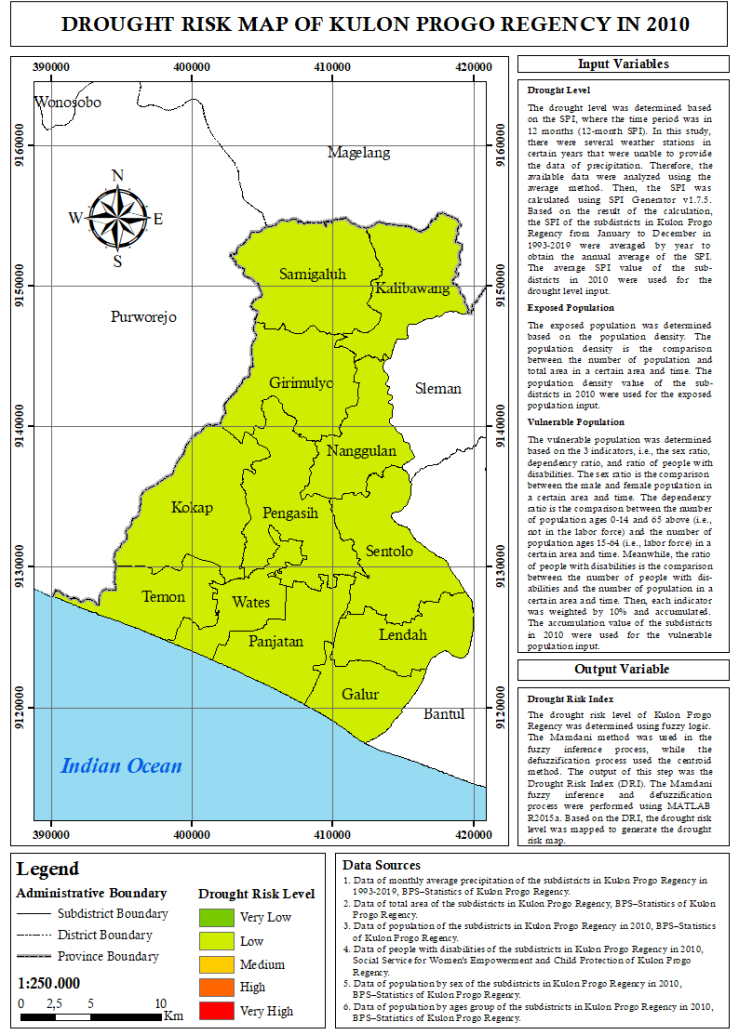

Figure 6. The drought risk map of Kulon Progo Regency in 2010

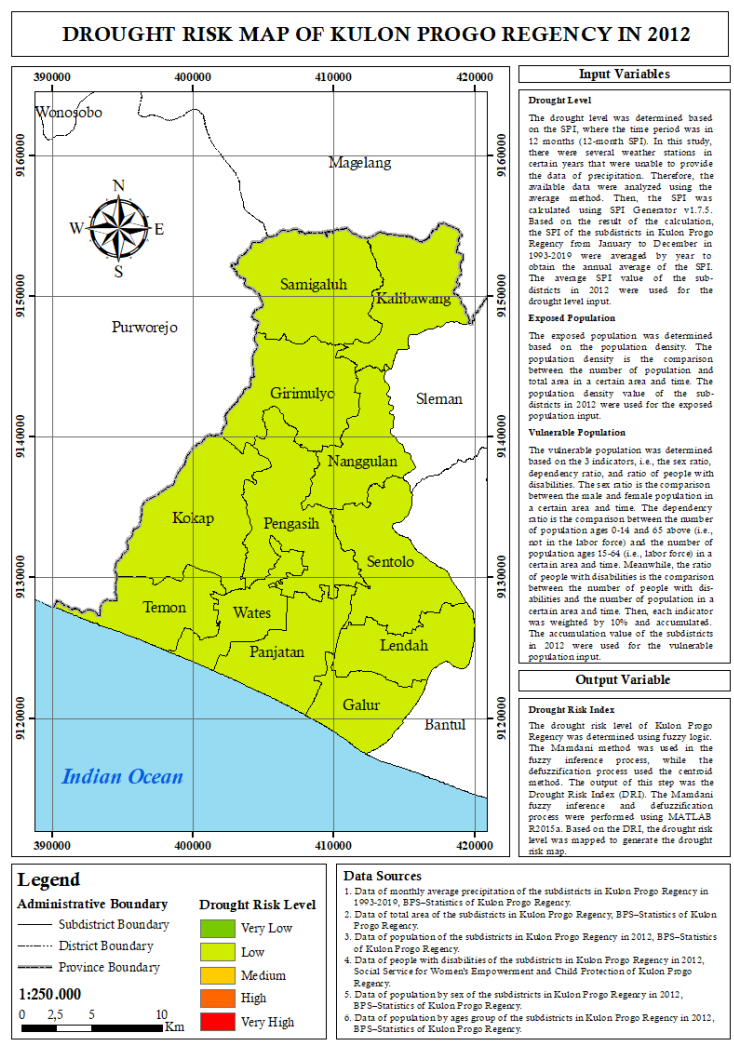

Figure 8. The drought risk map of Kulon Progo Regency in 2012

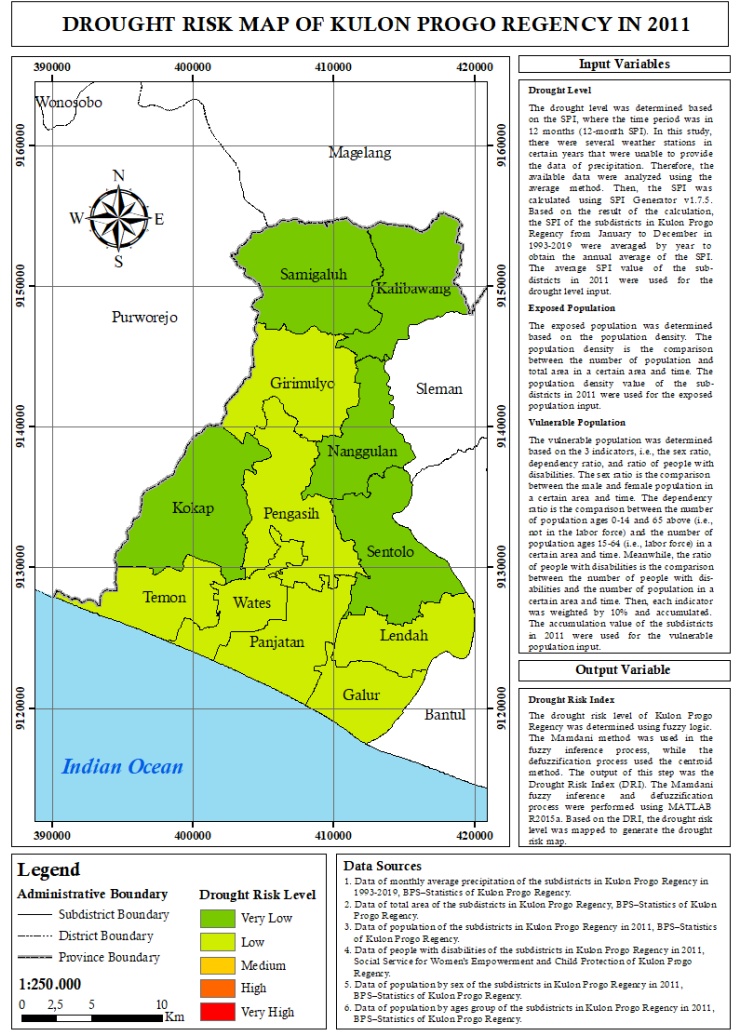

Figure 7. The drought risk map of Kulon Progo Regency in 2011

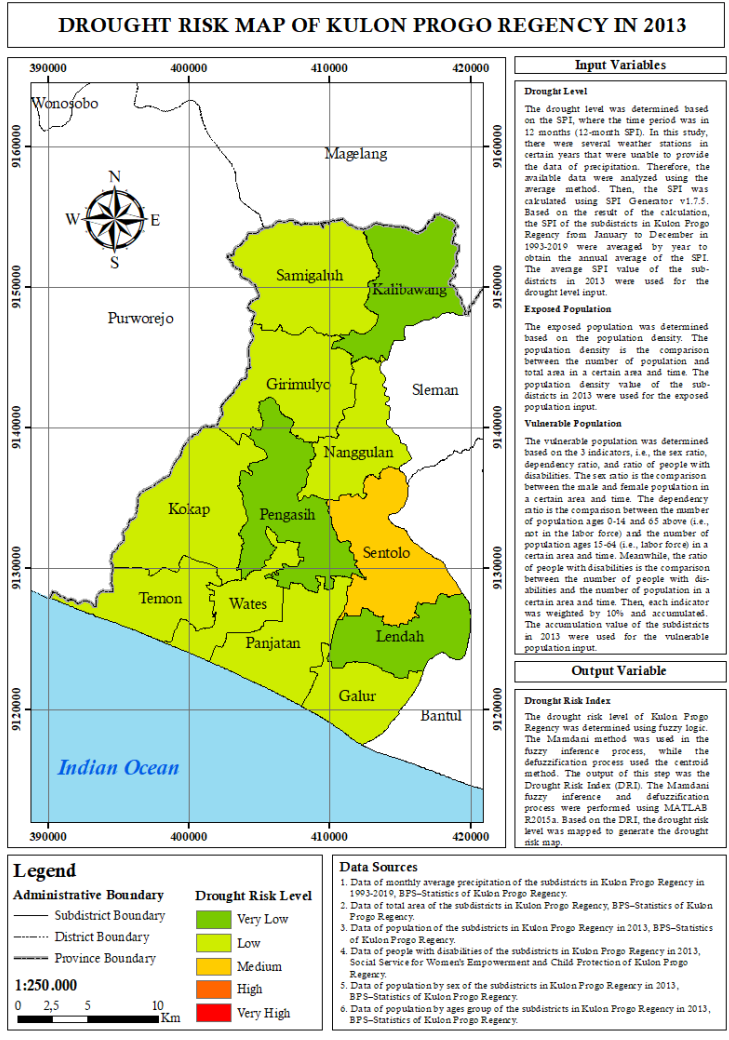

Figure 9. The drought risk map of Kulon Progo Regency in 2013 


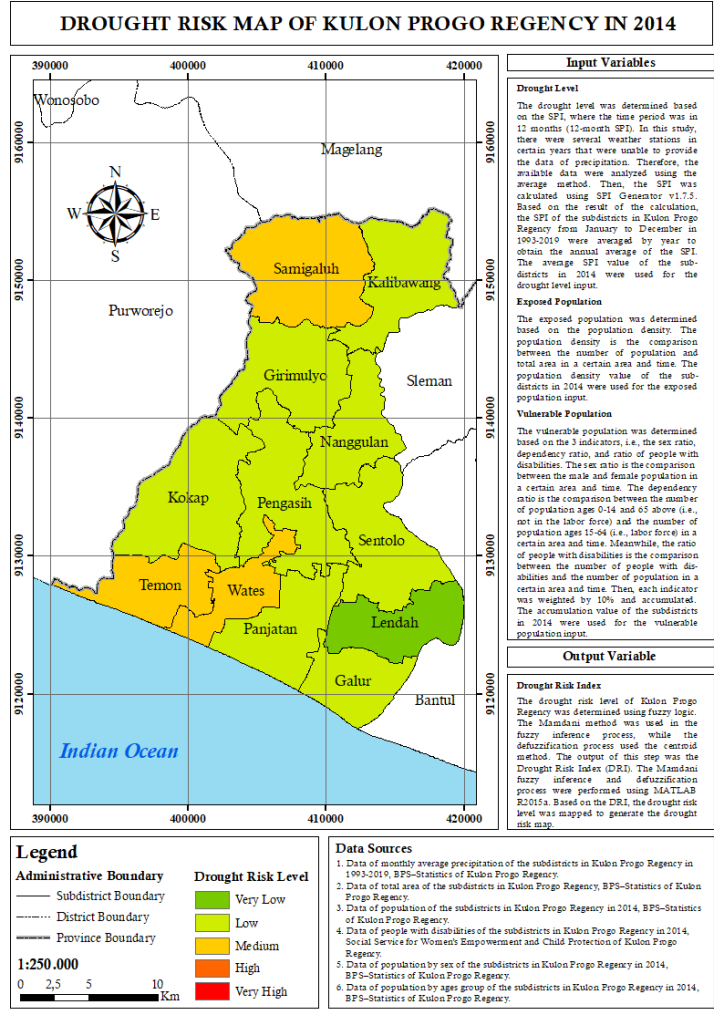

Figure 10. The drought risk map of Kulon Progo Regency in 2014

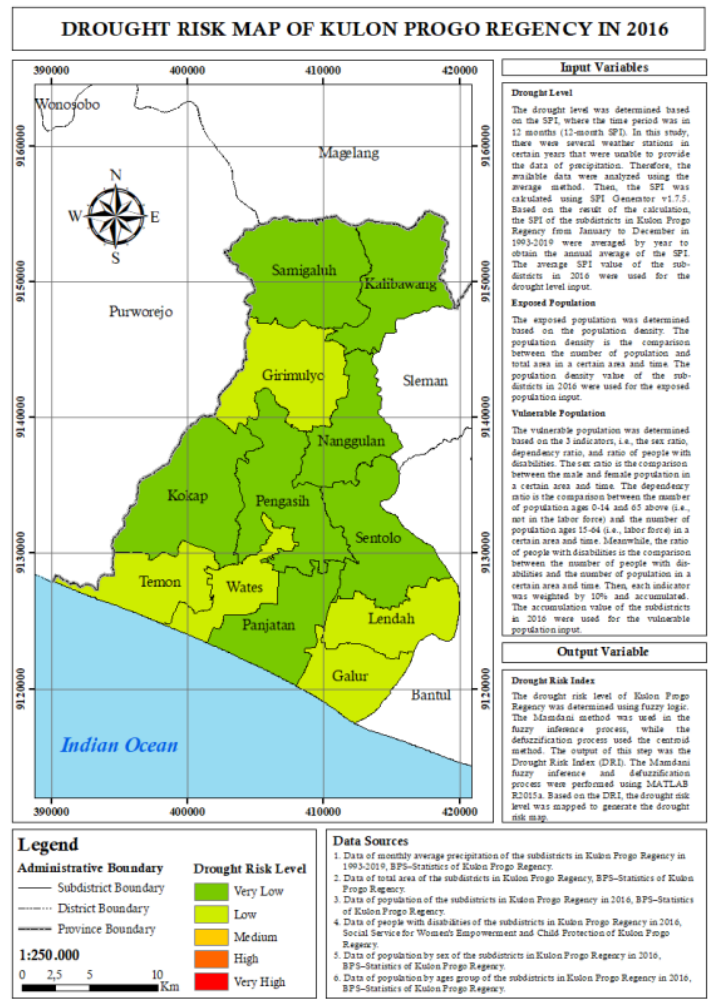

Figure 12. The drought risk map of Kulon Progo Regency in 2016

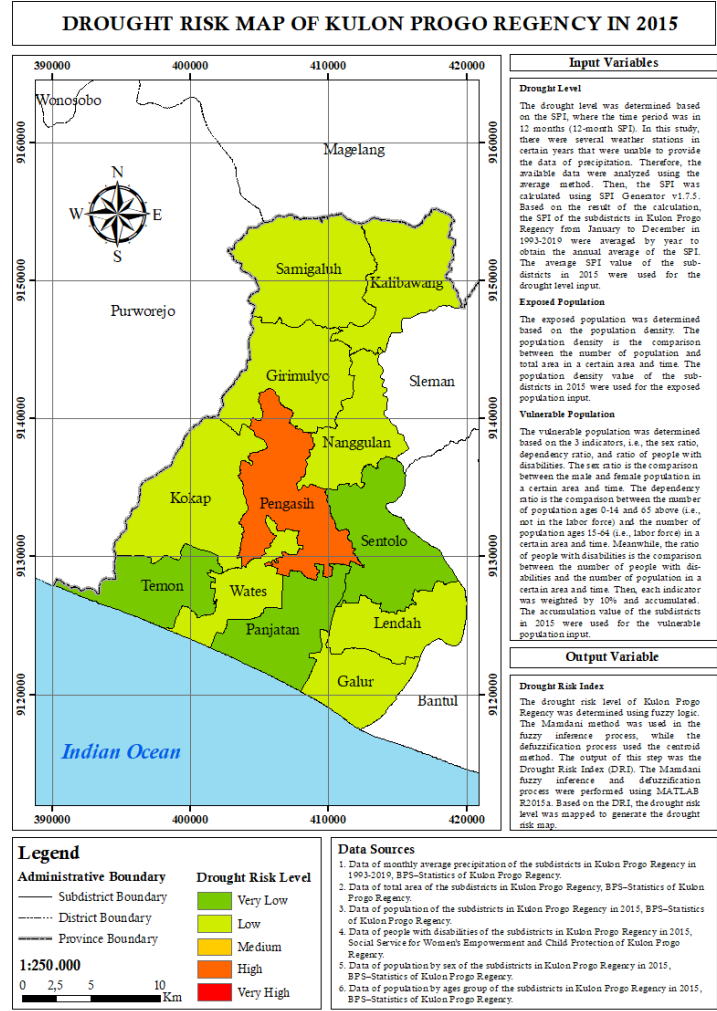

Figure 11. The drought risk map of Kulon Progo Regency in 2015

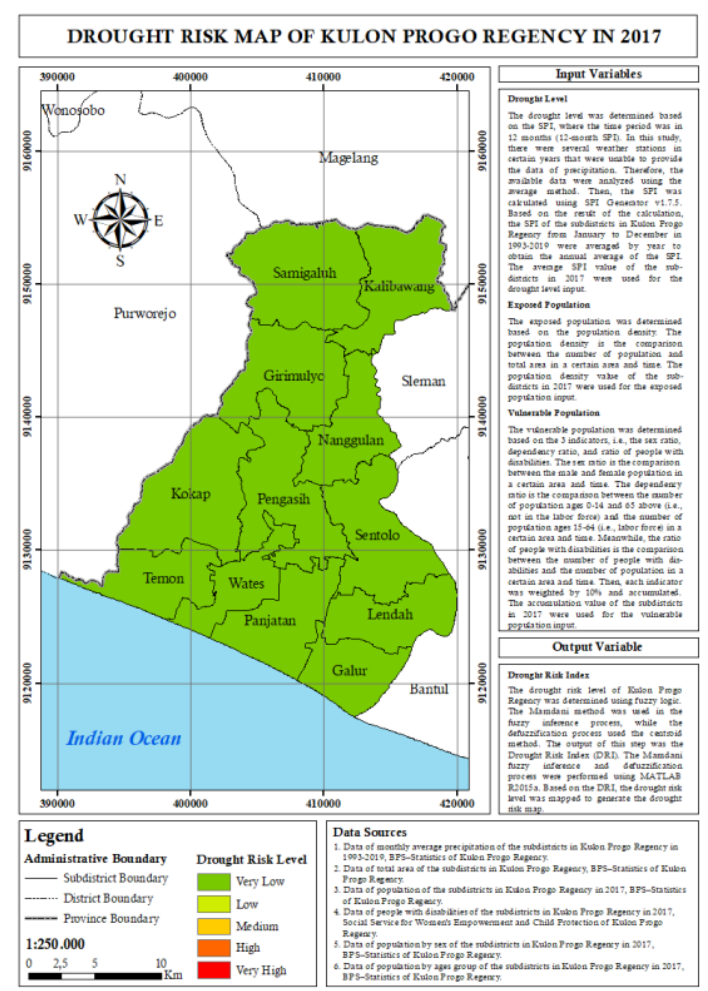

Figure 13. The drought risk map of Kulon Progo Regency in 2017 


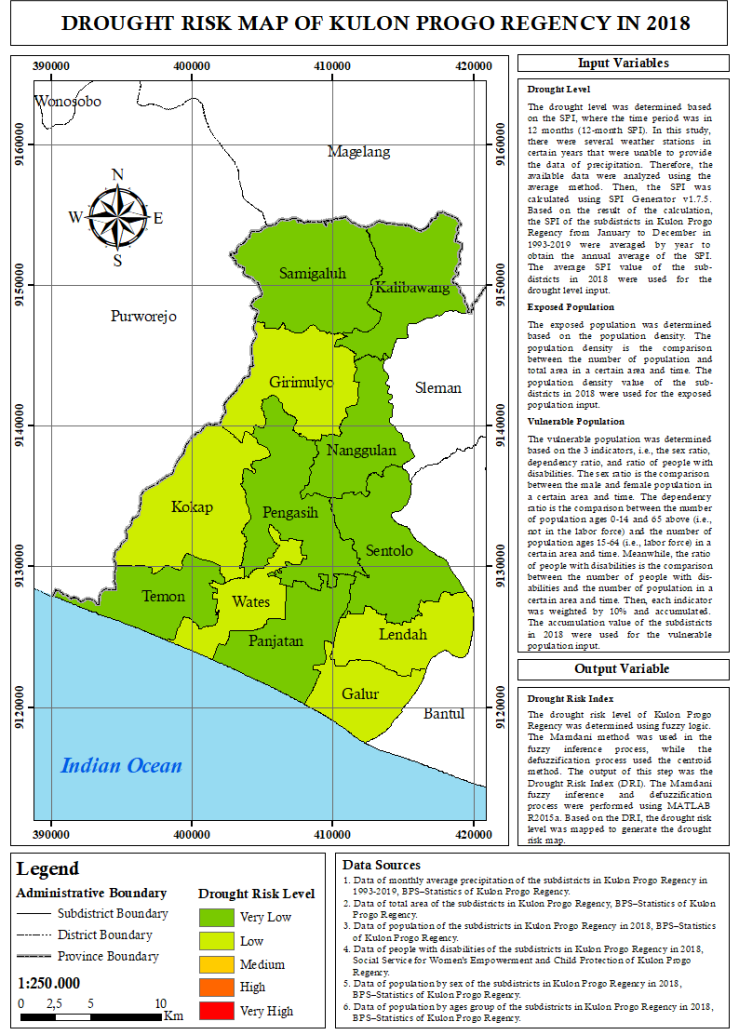

Figure 14. The drought risk map of Kulon Progo Regency in 2018

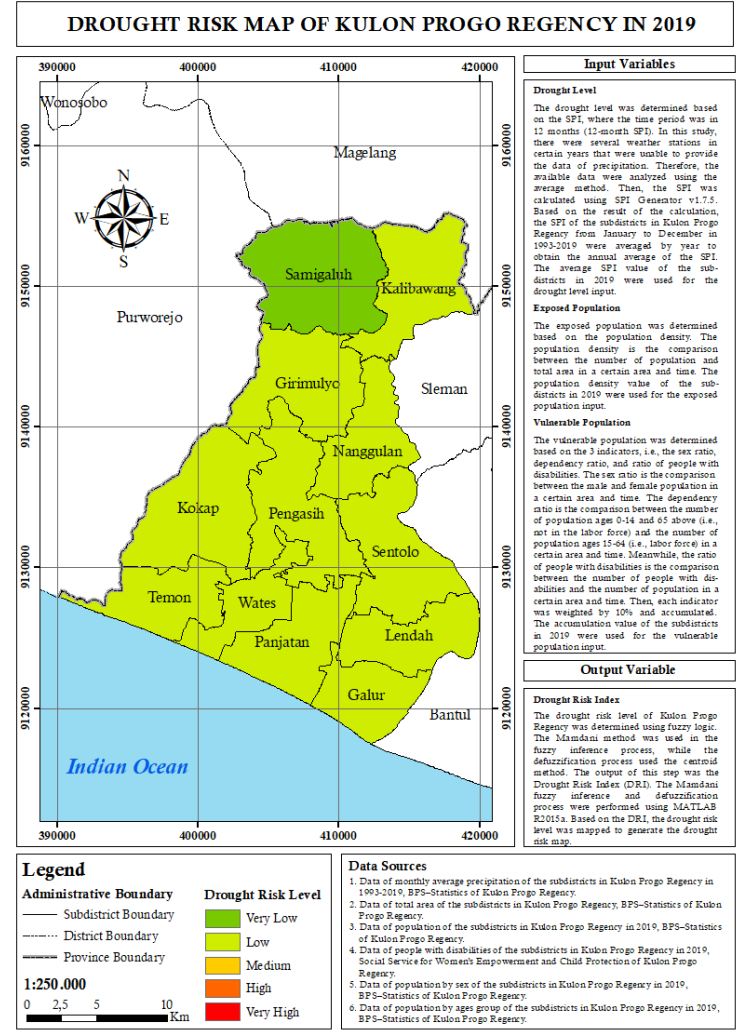

Figure 15. The drought risk map of Kulon Progo Regency in 2019

The drought risk maps of Kulon Progo Regency from 2010 to 2019 are shown in Figures 6 to 15 . Figures 6 to 11 and Figure 15 show that the drought risk level in 2010-2015 and 2019 were dominated by the low category. Meanwhile, Figures 12 to 14 show that the drought risk level in 2016-2018 was dominated by the very low category. In addition, based on the DRI average calculation, the subdistricts located in the southern region of Kulon Progo Regency had a higher risk than those in the middle and northern regions.

\section{Conclusion}

The result shows that the fuzzy logic can be used to determine the drought risk. The drought risk level of the subdistricts in Kulon Progo Regency were fluctuated from 2010 to 2019. The lowest risk occurred in several subdistricts in 2011, 2016,2017,2018, and 2019. The DRI indicates that the drought risk level was in the very low category. Meanwhile, the highest risk occurred in 2015. The DRI indicates that the drought risk level was in the high category. The drought risk level of Kulon Progo Regency in 2010-2015 and 2019 were dominated by the low category. Meanwhile, the drought risk level in 20162018 was dominated by the very low category. In addition, the subdistricts located in the southern region of Kulon Progo Regency had a higher risk than those in the middle and northern regions during the last 10 years.

\section{Acknowledgement}

This study is supported by the Regional Disaster Management Agency of Kulon Progo Regency, BPS-Statistics of Kulon Progo Regency, and Social Service for Women's Empowerment and Child Protection of Kulon Progo Regency.

\section{References}

[1] L. X. Wang, A Course in Fuzzy System and Control, New Jersey, Pretience Hall International, 1997.

[2] H. Singh, M. M. Gupta, T. Meitzler, Z. G. Hou, K. K. Garg, A. M. G. Solo, and L. A. Zadeh, Real-Life Applications of Fuzzy Logic, Advances in Fuzzy System, London, Hindawi Publishing Corporation, 2013. 
[3] M. Özger, A. K. Mishra, and V. P. Singh, Long Lead Time Drought Forecasting Using a Wavelet and Fuzzy Logic Combination Model: A Case Study in Texas, Journal of Hydrometeorology 13(2012) 284-297.

[4] S. M. Lewis, G. Fitts, M. Kelly, and L. Dale, A fuzzy logic-based spatial suitability model for drought-tolerant switchgrass in the United States, Computer and Electronics in Agriculture 103(2014) 39-47.

[5] A. Malik, A. Kumar, S. Q. Salih, S. Kim, N. W. Kim, Z. M. Yaseen, and V. P. Singh, Drought index prediction using advanced fuzzy logic model: Regional case study over Kumaon in India, San Francisco, PLOS ONE, 2020.

[6] D. A. Wilhite, Drought and Wates Crises: Science, Technology, and Management Issues, Broken Sound Parkway NW, Taylor \& Francis Group Press, 2005.

[7] Badan Nasional Penanggulangan Bencana (BNPB), Risiko Bencana Indonesia, Jakarta, BNPB, 2016.

[8] G. A. Dipayana, A. Cahyadi, and E. Nurjani, Analisis Trend Kejadian Kekeringan di Sebagian Wilayah di Propinsi D. I. Yogyakarta dan Dampak El-Nino Terhadapnya, Seminar Nasional Geografi, Surakarta, Universitas Muhammadiyah Surakarta, 2014.

[9] Z. Sun, J. Zhang, Q. Zhang, Y. Hu, D. Yan, and C. Wang, Integrated risk zoning of drought and waterlogging disasters based on fuzzy comprehensive evaluation in Anhui Province, China, Natural Hazards 71(2004) 1639-1657.

[10] F. I. Nurrahman and A. Pamungkas, Identifikasi Sebaran Daerah Rawan Bahaya Kekeringan Meteorologi di Kabupaten Lamongan, Jurnal Teknik POMITS, vol. 2, pp. 83-86, 2013.

[11] T. B. McKee, N. J. Doesken, and J. Kleist, The Relationship of Drought Frequency and Duration to Time Scales, Proceeding of 8th Conference on Applied Climatology, Boston MA, American Meteorological Society 17(1993)179-183.

[12] World Meteorological Organization (WMO), Standardized Precipitation Index User Guide, Geneva, World Meteorological Organization, 2012.

[13] Badan Pusat Statistik (BPS) Kabupaten Kulon Progo, Curah Hujan per Bulan Menurut Kecamatan di Kabupaten Kulon Progo, Kulon Progo, BPS Kabupaten Kulon Progo, 1993-2019.

[14] Badan Pusat Statistik (BPS) Kabupaten Kulon Progo, Proyeksi Penduduk Kabupaten Kulon Progo Tahun 2010-2020, Kulon Progo, BPS Kabupaten Kulon Progo, pp. 9-369, 2014.

[15] Dinas Sosial Pemberdayaan Perempuan dan Perlindungan Anak Kabupaten Kulon Progo, Persebaran Jenis PMKS Menurut Kecamatan di Kabupaten Kulon Progo, Kulon Progo, Dinsos P3A Kabupaten Kulon Progo, 2010-2019.

[16] F. Prawaka, A. Zakaria, and S. Tugiono, Analisis Data Curah Hujan yang Hilang dengan Menggunakan Metode Normal Ratio, Inversed Square Distance, dan Rata-Rata Aljabar (Studi Kasus Curah Hujan Beberapa Stasiun Hujan Daerah Bandar Lampung), Jurnal Rekayasa Sipil dan Desain 4(2016) 397-406

[17] Badan Nasional Penanggulangan Bencana (BNPB), Peraturan Kepala Badan Nasional Penanggulangan Bencana Nomor 02 Tahun 2012 tentang Pedoman Umum Pengkajian Risiko Bencana, Jakarta, BNPB, 2012.

[18] I. M. Sandy, Republik Indonesia Geografi Regional, Depok, Departemen Geografi FMIPA Universitas Indonesia, 1996.

[19] Badan Pusat Statistik (BPS) Kabupaten Kulon Progo, Kabupaten Kulon Progo Dalam Angka 2020, Kulon Progo, BPS Kabupaten Kulon Progo, 2019.

[20] G. J. Klir, U. S. Clair, and B. Yuan, Fuzzy Set Theory: Foundations and Applications, New Jersey, Pretience Hall International, pp. 222-229, 1997. 